\title{
KUNTOUTUSTA UUSIKSI?
}

\section{PÄÄKIRJOITUS}

SOILE KUITUNEN
Kuntoutus on osa hyvinvointipalvelujärjestelmää. Sillä on kiinteät yhteydet sosiaaliturvaan, ihmisten elantoon ja toimeentuloon. Kuntoutus on myös tulevaisuussuunnittelua. Kuntoutuspäätöksiä tehtäessä tehdään aina päätöksiä myös kuntoutujan elannosta, tulevaisuudesta ja tulevaisuuden näkymistä. Siitä, mikä on toivottua ja tavoittelemisen arvoista, mikä taas epätoivottavaa.

Kuntoutusjärjestelmässä on valtaa, rahaa, erilaisia päätöksentekorakenteita. A-klinikkasäätiön Olavi Kaukonen kuvasi oivaltavasti Kuntoutusverkoston (KUVE) kokouksessa 2.2.2017 kuntoutusta systeemisenä rakenteena ja sen uudistamisen haastetta. Kaukosen mukaan päihdekuntoutuksessa isoin siilo ei kulje työttömän ja työllisen välillä - kuten ehkä tapahtuu isossa kuvassa. Monet päihdekuntoutujista ovat "hyväosaisia", heidän ongelmanaan ei ole syrjäytyminen eikä aina työttömyyskään.

Päihdekuntoutujien kuntoutusjärjestelmä on repaleinen, mutta osa siitä toimii nykyisellään hyvin kuntoutujaa ajatellen. Järjestelmän yhdenmukaistaminen ja yksikanavainen rahoitus voisi tarkoittaa päihdekuntoutujille myös heikennyksiä. Pätee vanha viisaus: jos se toimii edes jotenkuten, älä korjaa.

Mitä kuntoutusjärjestelmälle sitten pitäisi tehdä? Kuntoutuskomitean asettamispäätöksessä todetaan, että "tavoitteena on yhdenvertainen, kustannustehokas ja ohjattava järjestelmä, jolla tuetaan ja vahvistetaan kuntoutujan arjessa, työssä ja opiskelussa pärjäämistä, kotona asumista ja aktiivista osallistumista sekä pidennetään työuria”.

Miten kuntoutukseen käytettävät kaksi miljardia euroa ja työllisyydenhoitoon käytettävät kuusi miljardia euroa voitaisiin käyttää tehokkaammin ja vaikuttavammin? Mikä on komitean toimeksiannossa mainittu valtakunnallisesti ja alueellisesti ohjattu ja koordinoitu järjestelmä? Edellyttääkö se yksikanavaista rahoitusjärjestelmää? Onko, kuten Olavi Kaukonen toteaa, repaleisuudessa omat vahvuutensa, kunhan eri rahoittajilla ja palveluiden järjestäjillä on riittävän yhdenmukaiset tavoitteet?

Blogissani "Kuntoutuksen kuumat perunat" (www.kuntoutusportti. fi) nostin esille kysymyksiä, jotka näen relevantteina kuntoutusjärjestelmää uudistettaessa. Aiemman kuntakokemukseni perusteella näen isona huolena sen, että kuntoutus on tulevassa maakunta- ja sote-rakenteessa "kaikkialla, ja juuri siksi ei juuri missään".

Olen samaa mieltä myös Olavi Kaukosen kanssa siitä, että jos järjestelmä toimii joillekin ja joiltakin osin, ei näitä toimivia osia pitäisi hukata. Tällaisia kohtuullisen hyvin toimivia osia ovat mielestäni ai- 
nakin Kela, sen järjestämä kuntoutus sekä tutkimus- ja kehittämistoiminta. Vaikka Kelan kuntoutuspalveluiden standardit ovat tiukkoja ja aiheuttavat aika ajoin harmaita hiuksia palvelutuottajille, niiden avulla on voitu turvata tasalaatuisuutta ja tasavertaisuutta palveluissa eri puolilla Suomea oleville kuntoutujille. Kelan tutkimus- ja kehittämisrahoitus on mahdollistanut korkeatasoista tutkimustyötä ja edistänyt uusien vaikuttavampien kuntoutusmuotojen käyttöönottoa.

Myös RAY:n avustusosaston seuraajan STEAn rooli kuntoutuksessa on iso sen rahoittaessa ja tukiessa järjestöjä niiden kuntoutustoiminnassa. Järjestöt toimivat juuri siellä, minne julkisen palvelujärjestäjän kynnet eivät yllä ja minne raha ei tunnu riittävän. Järjestöillä on jäsenistönsä kautta valtava kokemusasiantuntijuuden voimavara. Niissä kuntoutuksen kehittäminen on ketterää ja käytäntölähtöistä, arkeen nivoutuvaa sekä välittömiä tuloksia ja hyvinvointia tuottavaa.

Iso hyvinvointiyhteiskunnan perusteisiin menevä kysymyksensä liittyy työeläkeyhtiöiden ja vakuutuspohjaisen järjestelmän ja toisaalta valtio- ja verorahoitteisen järjestelmän väliseen dynamiikkaan. Joidenkin asiantuntijoiden mielestä Suomea ollaan kovaa kyytiä viemässä kohti vakuutuspohjaista järjestelmää - muun muassa työterveyshuoltoa koskevan erillisratkaisun nojalla. Työeläkeyhtiöillä on isot resurssit ja valta kuntoutuksessa. Onko niiden yhteiskuntavastuuta syytä kasvattaa, erityisesti työttömien työhön kuntoutumisessa?

On selvää, että kuntoutusjärjestelmän uudistaminen on kytköksissä koko yhteiskunnan ja hyvinvointipalvelujärjestelmän isoihin kysymyksiin. Nämä ovat kuumia perunoita, jotka herättävät poltetta ja aikaansaavat myös isoja jakolinjoja.

Soile Kuitunen, VTT,

toimitusjohtaja, Kuntoutussäätiö 